\title{
Carotenoid exposure of Caco-2 intestinal epithelial cells did not affect selected inflammatory markers but altered their proteomic response
}

\author{
Anouk Kaulmann, Tommaso Serchi, Jenny Renaut, Lucien Hoffmann and Torsten Bohn* \\ Environmental-and Agro-Biotechnologies Department, Centre de Recherche Public - Gabriel Lippmann, 41, rue du Brill, \\ Belvaux, L-4422, Luxembourg \\ (Submitted 25 January 2011 - Final revision received 3 October 2011 - Accepted 8 October 2011 - First published online 12 December 2011)
}

\section{Abstract}

Carotenoid consumption has been linked to a number of beneficial health effects, including the reduction of chronic diseases such as cancer and cardiovascular complications. However, no data are available on their action on the intestinal epithelium, being exposed to the highest concentrations of carotenoids in the human body, and where they could act preventively on intestinal inflammatory diseases such as Crohn's disease and ulcerative colitis. The objective of the present study was to investigate whether lycopene and $\beta$-carotene in micelles (M), at concentrations that could be reached via the diet $(10-25 \mu \mathrm{g} / \mathrm{ml})$ could aid in the reduction of TNF- $\alpha$ plus IL-1 $\beta$-induced inflammation of Caco-2 human epithelial cells. The impact on biomarkers of inflammation, including IL-8, NO and cyclo-oxygenase-2 (through PGE- $2 \alpha$ ), and the NF- $\mathrm{KB}$ and mitogen-activated protein kinase (MAPK) pathways of intracellular signalling cascades were evaluated compared with controls (empty M). Furthermore, proteomic analyses were conducted from total cellular protein extracts. The results revealed that isolated carotenoids had no statistical significant anti-inflammatory effect on the biomarkers observed, or on the regulation of NF- $\mathrm{KB}$ and MAPK. Nevertheless, analyses of the proteome suggested that fifteen proteins were significantly $(P<0 \cdot 05$, expression ratio $>1.3$ ) differentially regulated following $\beta$-carotene exposure, participating mostly in metabolic activities including antioxidant mechanisms, such as glutathione $S$-transferase A1. Only one protein was differentially regulated by lycopene (profilin-1). To our knowledge, this is the first attempt to investigate pathways involved in the action of carotenoids on the intestinal epithelium.

Key words: Carotenoids: Inflammation: Intestinal epithelium: Caco-2 cells: Proteomics

Carotenoids are lipid-soluble, C-40-based pigments that can be synthesised by vegetables and fruits and certain fungi, but not by animals including humans. Of the approximately 700 identified carotenoids, only about fifty are of importance in the human $\operatorname{diet}^{(1)}$. In addition to the well-known provitamin A activity of several carotenoids, it has been suggested that carotenoids have further beneficial effects, including the prevention of cancer ${ }^{(2,3)}, \mathrm{CVD}^{(4,5)}$ and diabetes ${ }^{(6,7)}$. Carotenoids can act as antioxidants with the potential to remove free radicals, either by a direct reaction with radicals, resulting in the formation of harmless products, or by disrupting radical chain reactions, avoiding further damage of cellular compounds, such as membrane lipids. There exists a growing awareness that oxidative stress and the resulting inflammation play an important role in the development of several chronic diseases ${ }^{(8)}$, including cancer ${ }^{(9)}$, diabetes ${ }^{(6)}$ and inflammatory bowel diseases $(\mathrm{IBD})^{(10)}$. It has been shown that reactive oxygen species can activate several signal transduction pathways such as the mitogen-activated protein kinase (MAPK) signalling cascade, as well as amplifying the activation of the nuclear transcription factor $\mathrm{NF}-\mathrm{\kappa B}^{(11)}$, both resulting in enhanced formation of pro-inflammatory mediators such as cytokines $^{(12)}$.

Ulcerative colitis (UC) and Crohn's disease (CD) are the most predominant IBD, affecting over $2 \cdot 2$ million people of the European population, with a continuous increase over the past decades (www.efcca.org), with reasons remaining speculative, but including increased hygienic conditions and decreased immune stimulation ${ }^{(13)}$. Pathological complications of IBD may result following redox-mediated dysregulation of signalling cascades and/or gene expression ${ }^{(11)}$. Major intracellular signalling cascades that are responsible for the production of inflammatory molecules include NF- $\mathrm{B}$ and MAPK, modulating action via their regulation and induction of target genes ${ }^{(14)}$. The resulting inflammation of the small (mainly CD) and large (both CD and UC) intestinal epithelium

\footnotetext{
Abbreviations: 2D-DIGE, two-dimensional differential in-gel electrophoresis; B, blank; CD, Crohn's disease; COX-2, cyclo-oxygenase-2; DMEM, Dulbecco's modified Eagle's medium; IBD, inflammatory bowel disease; JNK, c-Jun N-terminal kinases; M, micelles; MAPK, mitogen-activated protein kinase; S, stimulus; UC, ulcerative colitis.
} 
is chronic, has a low remission rate to medical treatment such as corticosteroids or non-steroidal anti-inflammatory $\operatorname{agents}^{(15,16)}$, and may develop into cancer ${ }^{(15,16)}$. Thus, the search for preventive strategies targeting the onset of inflammation in the gut is paramount.

The implication of carotenoids in inflammatory processes in the human body is only marginally understood. It was noted that patients affected by early-stage IBD had low serum concentrations of micronutrients including Se and $\beta$-carotene ${ }^{(17)}$, with similar results for several carotenoids in $\mathrm{CD}^{(10,18)}$ and UC and CD subjects ${ }^{(19)}$. On the other hand, markers of oxidative stress or inflammation including TNF- $\alpha$, IL- $1 \beta$ and lipid peroxidation were increased in adult subjects with $\mathrm{CD}^{(20,21)}$, as was oxidative DNA damage ${ }^{(22)}$. Also increased NO was found as a mediator of inflammation in subjects with UC and $\mathrm{CD}^{(23,24)}$, and was present in higher concentration in intestinal epithelial cells of IBD patients. Thus, it could be hypothesised that there exists a relationship between low antioxidant status and increased inflammation. However, carotenoid absorption is typically low ${ }^{(1)}$ and carotenoid concentration decreases from the food matrix to the tissues. As the concentration of carotenoids is highest in the intestine, it is possible that their effect in this tissue is comparatively pronounced.

In the present study, the aim was to investigate the potential of carotenoids to interfere with inflammatory processes in the gut epithelium. For this purpose, differentiated human intestinal Caco- 2 cells stimulated for inflammation with TNF- $\alpha$ and IL-1 $\beta$ were exposed to lycopene and $\beta$-carotene emulsified in artificial micelles, and inflammatory markers including IL-8, NO, cyclo-oxygenase-2 (COX-2) activity via PGE-2 $\alpha$ measurement, as well as the signalling molecules NF- $\mathrm{BB}$ and MAPK were investigated. In addition, a proteomic study on extracted proteins from the whole cellular lysate following carotenoid exposure was performed using two-dimensional differential in-gel electrophoresis (2D-DIGE).

\section{Materials and methods}

\section{Chemicals}

All products were of analytical grade or higher. Unless otherwise stated, all chemicals including oleic acid, mono-olein, L- $\alpha$-phosphatidylcholine, IL-8, lipopolysaccharide, TNF- $\alpha$, sodium taurocholate hydrate, resazurine, arachidonic acid, penicillin/streptomycin mixture and non-essential amino acids were procured from Sigma-Aldrich. High-purity $(18 \mathrm{~m} \Omega)$ water was prepared with a purification system from Millipore and used throughout. Lycopene was purchased from Extrasynthèse and $\beta$-carotene was purchased from Dr Ehrenstorfer GmbH.

\section{Cell culture}

The TC-7 subclone (ATCC no. HTB-37) of the Caco-2 parental cell line was derived from a tumour isolated by J. Fogh ${ }^{(25)}$ and was a generous gift from Monique Rousset (Nancy University). Cultures were routinely maintained in $75 \mathrm{~cm}^{2}$ plastic flasks
(Nunclon ${ }^{\mathrm{TM}}$; Nunc) at $37^{\circ} \mathrm{C}$ and $10 \% \mathrm{CO}_{2}$ in a CB-210 $\mathrm{CO}_{2}$ incubator (Binder $\mathrm{GmbH}$ ). Cells were grown in Dulbecco's modified Eagle's medium (DMEM + GlutaMAX ${ }^{\mathrm{TM}}$; Gibco), supplemented with $1 \%$ non-essential amino acids, $20 \%$ heat-inactivated fetal bovine serum (Gibco), $1 \%$ of a mixture of penicillin and streptomycin (10000 units and $10 \mathrm{mg} / \mathrm{ml}$, respectively) and subcultured weekly after reaching an approximately $80 \%$ confluence. For all experiments, 1-week differentiated cells were used (passage 50-81). Transepithelial electrical resistance, a valid method for determining epithelial tightness and cellular differentiation, was used to evaluate the differentiation status of the cells, and no statistical significant differences were found compared with 2 weeks of differentiation.

\section{Preparation of artificial micelles}

For the preparation of artificial micelles, the original protocol of Biehler et al. ${ }^{(26)}$ was adapted. In short, for the preparation of the medium, $0 \cdot 11 \mathrm{~g}$ sodium taurocholate were weighed into a $100 \mathrm{ml}$ glass vial, and $100 \mathrm{ml}$ DMEM + glutamax $(20 \%$ fetal bovine serum, $1 \%$ non-essential amino acids and $1 \%$ penicillin and streptomycin) were added under a laminar flow box. In parallel, $12.8 \mathrm{mg} \mathrm{L}-\alpha$-phosphatidylcholine, $18.0 \mathrm{mg}$ monoolein and $1.0 \mathrm{mg}$ oleic acid were weighed on a six-digit balance (Metler Toledo) into another $100 \mathrm{ml}$ glass vial. The vial was enwrapped with aluminium foil and kept on ice. Next, $4.0 \mathrm{mg}$ of either lycopene or $\beta$-carotene were dissolved in $8 \mathrm{ml}$ chloroform. Then, $2 \mathrm{ml}$ (for $10 \mathrm{mg} / \mathrm{l}$ ) or $5 \mathrm{ml}$ (for $25 \mathrm{mg}$ / 1) of these solutions were added into the enwrapped $100 \mathrm{ml}$ glass vial and the organic solvent was removed under a stream of $\mathrm{N}_{2}$ during $5 \mathrm{~min}$. Finally, $100 \mathrm{ml}$ of the prepared medium described above were added and the mixture sonicated for a total of $30 \mathrm{~min}$. After sonication, the solution appeared clear and no unsolubilised residues were visible. The last step consisted of a sterile filtration under a laminar flow box through a $0.22 \mu \mathrm{m}$ filter (PALL Life Sciences). The mixture was then divided into aliquots and stored at $-80^{\circ} \mathrm{C}$ until usage. In parallel, micelles without lycopene and $\beta$-carotene were prepared as negative controls.

\section{Cell viability}

To test the viability of the cells, especially following exposure to artificial micelles, the resazurine assay was used. Resazurine is a water-soluble dye, which can pass through cellular membranes. In the mitochondria, the oxidised blue resazurine is then reduced to the highly fluorescent pink compound resorufin, its amount being directly proportional to cell viability. Cells were exposed for $24 \mathrm{~h}$ to artificially produced micelles with or without carotenoids, and to pro-inflammatory cytokines used to induce inflammation (100 ng TNF- $\alpha / \mathrm{ml}$ together with $25 \mathrm{ng} \mathrm{IL}-1 \beta / \mathrm{ml}$ ). After the treatment, cells were washed with basal medium (DMEM + GlutaMAX $^{\mathrm{TM}}$, supplemented with 1\% non-essential amino acids, 20\% heatinactivated fetal bovine serum, $1 \%$ of a mixture of penicillin (10 000 units) and streptomycin $(10 \mathrm{mg} / \mathrm{ml})$, respectively) and incubated for $2 \mathrm{~h}$ with a medium containing $400 \mu \mathrm{m}$-resazurine 
in the dark $\left(37^{\circ} \mathrm{C}, 90 \%\right.$ air, $\left.10 \% \mathrm{CO}_{2}\right)$. Fluorescence was measured in a BioTek Synergy 2 plate reader, with excitation at $530 \mathrm{~nm}(530(25) \mathrm{nm}$ filter $)$ and emission recorded at $590 \mathrm{~nm}$ (590 (25) nm filter). Cell viability is expressed as mean cell viability (in \%) compared with cells without treatment (set at $100 \%)$.

Exposure experiments for studying IL-8, NO and PGE-2 $\alpha$, mitogen-activated protein kinase and NF- $\kappa B$

Cells were grown on twenty-four-well plates (BD Biosciences) and six different treatments were performed (Table 1). To each well, a total volume of $10 \mu \mathrm{l}$ TNF- $\alpha(10 \mu \mathrm{g} / \mathrm{ml})$ and $10 \mu \mathrm{l}$ IL-1 $\beta(25 \mu \mathrm{g} / \mathrm{ml})$ was added. Each experiment was performed on three different days (except for NF-кB and MAPK on $n 4$ different days), with each individual treatment done as duplicates (IL-8, PGE-2 $\alpha$ and NO). Secretion of IL-8, PGE2 and $\mathrm{NO}$ is expressed as percentage of the positive control (blank (B) + micelles (M) + stimulus (S))

In order to verify uptake of the carotenoids by cells, Caco-2 cells grown on six-well plates (BD Biosciences) and incubated for $4 \mathrm{~h}$ at $37^{\circ} \mathrm{C}$ with $2 \mathrm{ml}$ of the prepared medium/micelle mixture, containing either lycopene $(10$ or $25 \mu \mathrm{g} / \mathrm{ml})$ or $\beta$-carotene (10 or $25 \mu \mathrm{g} / \mathrm{ml}$ ), were extracted and analysed as described earlier ${ }^{(26)}$.

\section{Determination of IL-8 secretion}

IL-8 concentration in the supernatant was measured by an enzyme immunoassay kit from BD OptEIA (Becton Dickinson), according to the manufacturer's recommendation. In short, $50 \mu \mathrm{l}$ ELISA diluent and $100 \mu \mathrm{l}$ of the supernatant were added to a ninety-six-well plate, which was pre-coated with a monoclonal antibody for human IL-8. The plate was incubated for $2 \mathrm{~h}$ and washed before the addition of the monoclonal IL- 8 antibody and streptavidin-horseradish peroxidase. The plate was again incubated for $1 \mathrm{~h}$, washed with washing buffer and $100 \mu \mathrm{l}$ substrate of horseradish peroxidase (tetramethylbenzidine; 3,3',5,5'-tetramethylbenzidine) was added. Finally, following another incubation of $30 \mathrm{~min}$, stop solution (1 M-phosphoric acid) was added and absorbance was read at $450 \mathrm{~nm}$ in a BioTek Synergy 2 plate reader. IL-8 concentration $(\mathrm{pg} / \mathrm{ml})$ was calculated using an external IL-8 standard curve.

\section{Determination of cyclo-oxygenase-2 activity}

Cells were treated as described above; however, to induce COX-2 activity, cells were additionally incubated for $10 \mathrm{~min}$ with arachidonic acid (10 $\mathrm{mm}$ in PBS). Concentration of PGE$2 \alpha$ in the supernatant was determined using the PGE-2 enzyme immunoassay kit from Cayman Chemical following the manufacturer's instructions. Briefly, $50 \mu \mathrm{l}$ of culture medium, PGE-2-acetylcholinesterase conjugate and PGE- $2 \alpha$ monoclonal antibodies were added to a ninety-six-well plate supplied with the kit. This goat polyclonal anti-mouse IgG antibody pre-coated plate was incubated for $18 \mathrm{~h}$ at $4^{\circ} \mathrm{C}$. The plate was then washed to remove unbound reagents and $200 \mu \mathrm{l}$ reagent (substrate for the acetylcholinesterase) was added. The plate was again incubated for $90 \mathrm{~min}$ at room temperature and absorbance read at $412 \mathrm{~nm}$ in a BioTek Synergy 2 plate reader. The concentration of PGE- $2 \alpha(\mathrm{pg} / \mathrm{ml})$ was determined by external calibration curves.

\section{Determination of NO secretion}

$\mathrm{NO}$ is unstable and is rapidly oxidised into nitrate $\left(\mathrm{NO}_{3}^{-}\right)$and nitrite $\left(\mathrm{NO}_{2}^{-}\right)$. The measurement of $\mathrm{NO}$ (as $\mathrm{NO}_{3}^{-}$and $\mathrm{NO}_{2}^{-}$) was carried out by the Nitric Oxide Assay Kit from Calbiochem (Merck KGaA) and was based on the Griess assay (40). The Griess reagent, however, does not measure nitrate, therefore the NADPH-dependent enzyme, nitrate reductase, was used to convert the nitrate to nitrite before quantification. Briefly, $85 \mu \mathrm{l}$ of culture medium were added to a ninety-six-well plate. Then nitrate reductase $(10 \mu \mathrm{l})$ and NADH $(10 \mu \mathrm{l})$ were added to the wells. The plate was incubated for $20 \mathrm{~min}$ at room temperature. Next, the Griess reagent $(100 \mu \mathrm{l})$ was added and the plate was shaken for $5 \mathrm{~min}$ before reading absorbance at $540 \mathrm{~nm}$ in a BioTek Synergy 2 plate reader. The concentration of NO $(\mu \mathrm{M})$ present in the samples was calculated by means of an external standard curve.

\section{Determination of NF- $\kappa B$}

Cells were grown in $75 \mathrm{~cm}^{2}$ plastic flasks (Nunclon ${ }^{\mathrm{TM}}$; Nunc) and five different treatments (with $n 4$ replicas each) were performed. Cells were treated as described above; only lycopene at $10 \mu \mathrm{g} / \mathrm{ml}$ was omitted due to reagent limitations. The nuclear extract was obtained from the cultured cells by using the Cayman Nuclear Extraction kit (Cayman Chemical). Briefly, $10^{7}$ cells were collected and centrifuged at $300 \mathbf{g}$ for $5 \mathrm{~min}$ at $4^{\circ} \mathrm{C}$. The supernatant was discarded and the cells were resuspended in PBS containing phosphatase inhibitors, and centrifuged again. This step was repeated before the addition of hypotonic buffer $(500 \mu \mathrm{l})$. The cells were then incubated on ice for $15 \mathrm{~min}$, before detergent addition (10\% Nonidet P-40 Assay Reagent, $50 \mu \mathrm{l}$ ) and centrifuged for

Table 1. Exposure of 1-week differentiated Caco-2 epithelial cells to various carotenoid treatments ( $n 6$ per treatment)

\begin{tabular}{ll}
\hline Exposure group & Treatment of cells \\
\hline Blank & Untreated: no inflammatory stimuli or micelles \\
Blank + micelles (negative control) & $24 \mathrm{~h}$ with empty micelles \\
Blank, micelles + stimuli (positive control) & TNF- $\alpha, \mathrm{IL} 1-\beta^{*}(28 \mathrm{~h})$ and empty micelles $(4-28 \mathrm{~h})$ \\
Blank, micelles, stimuli + all-trans-lycopene $(10$ or $25 \mu \mathrm{g} / \mathrm{ml})$ & $\mathrm{TNF}-\alpha, \mathrm{IL} 1-\beta(28 \mathrm{~h})$ and micelles containing 10 or $25 \mu \mathrm{g}$ lycopene $/ \mathrm{ml}(4-28 \mathrm{~h})$ \\
Blank, micelles, stimuli + all-trans $\beta$-carotene $(10$ or $25 \mu \mathrm{g} / \mathrm{ml})$ & $\mathrm{TNF}-\alpha, \mathrm{IL} 1-\beta(28 \mathrm{~h})$ and micelles containing 10 or $25 \mu \mathrm{g} \beta-$ carotene $/ \mathrm{ml}(4-28 \mathrm{~h})$ \\
\hline
\end{tabular}

* $25 \mathrm{ng} \mathrm{IL-1 \beta /ml} \mathrm{and} 100 \mathrm{ng}$ TNF- $\alpha / \mathrm{ml}$ simultaneously. 
$30 \mathrm{~s}$ at $4^{\circ} \mathrm{C}$. The supernatant containing the cytosolic fraction was transferred to a $1.5 \mathrm{ml}$ microcentrifuge tube and stored at $-80^{\circ} \mathrm{C}$ until analysis. Pellets were resuspended in $50 \mu \mathrm{l}$ nuclear extraction buffer (containing protease and phosphatase inhibitors and dithiothreitol) and incubated on ice (15 min). This step was repeated before centrifugation at $14000 \mathrm{~g}\left(10 \mathrm{~min}, 4^{\circ} \mathrm{C}\right)$. The supernatant was transferred to a $1.5 \mathrm{ml}$ microcentrifuge tube and was either further examined or stored at $-80^{\circ} \mathrm{C}$ until analysis.

The concentration of NF- $\mathrm{BB}$ was measured by the NF- $\mathrm{BB}$ (p65) ELISA kit (Cayman Chemical) following the manufacturer's protocol. In short, $90 \mu \mathrm{l}$ of complete transcription factor buffer and $10 \mu \mathrm{l}$ of the nuclear extract were added to a ninety-six-well plate and incubated overnight at $4^{\circ} \mathrm{C}$. The plate was pre-coated with a consensus double-stranded DNA sequence containing the NF- $\mathrm{B}$ response element. After incubation, the plate was washed five times with $200 \mu$ l wash buffer, and the primary antibody added. The plate was covered and incubated for $1 \mathrm{~h}$ at room temperature. Following incubation, the plate was again washed with wash buffer and a second antibody conjugated to horseradish peroxidase was added. The plate was covered and incubated for $1 \mathrm{~h}$ at room temperature. After incubation, the plate was washed with $200 \mu \mathrm{l}$ wash buffer, and $100 \mu \mathrm{l}$ developer solution was added. The colorimetric development was monitored between 15 and $45 \mathrm{~min}$, and $100 \mu \mathrm{l}$ stop solution was added. The absorbance was read at a wavelength of $450 \mathrm{~nm}$ in a BioTek Synergy 2 plate reader.

\section{Determination of mitogen-activated protein kinase activation}

Cells were grown and exposed as described for NF- $\mathrm{B}$ (with $n 4$ replications for each of the five exposures). The nuclear extract was obtained by following the cell extraction protocol of the p38 MAPK Immunoassay Kit (Invitrogen). The cells were collected in PBS by scraping them from the culture flasks. Then, two washing steps with PBS followed by centrifugation for $1 \mathrm{~min}$ at $16500 \mathrm{~g}$ were performed and the supernatant was discarded. The cell pellet was lysed in cell extraction buffer for $30 \mathrm{~min}$ on ice and was vortexed every $10 \mathrm{~min}$. The extract was then transferred to a $1.5 \mathrm{ml}$ microcentrifuge tube and centrifuged for $10 \mathrm{~min}$ at $18000 \mathrm{~g}$ at $4^{\circ} \mathrm{C}$. The lysate was divided into aliquots into $1.5 \mathrm{ml}$ microcentrifuge tubes. The nuclear extracts $(100 \mu \mathrm{l})$ were added to anti-p38 antibody pre-coated ninety-six-well plates. After $2 \mathrm{~h}$ of incubation, the wells were washed with wash buffer $(200 \mu \mathrm{l})$ and $100 \mu \mathrm{l}$ anti-p38 MAPK antibody was added. The plate was incubated for another $1 \mathrm{~h}$ and after an additional washing step with $200 \mu$ l wash buffer, $100 \mu \mathrm{l}$ horseradish peroxidase-labelled anti-rabbit IgG were added. After a third incubation and washing step with $200 \mu \mathrm{l}$ wash buffer, a chromogen (tetramethylbenzidine) was added and $30 \mathrm{~min}$ later, the reaction was stopped by adding $100 \mu \mathrm{l}$ stop solution and the absorbance read at $450 \mathrm{~nm}$ in a BioTek Synergy 2 plate reader. The concentration of MAPK $(\mathrm{pg} / \mathrm{ml})$ present in the samples was calculated by external calibration curves.
Proteomic analyses following carotenoid exposure of Caco-2 cells

For 2D-DIGE, an earlier protocol ${ }^{(27)}$ was adapted. Unless otherwise stated, materials were from GE Healthcare. For each treatment $(\mathrm{B}, \mathrm{B}+\mathrm{M}, \mathrm{B}+\mathrm{M}+\mathrm{S}$, lycopene $10 \mu \mathrm{g} / \mathrm{ml}$ and $\beta$-carotene $10 \mu \mathrm{g} / \mathrm{ml}$ or $25 \mu \mathrm{g} / \mathrm{ml}$ ), four TC175 flasks (Nunclon ${ }^{\mathrm{TM}}$; Nunc) were used to obtain sufficient biological cellular material. The total protein extract from the Caco-2 cells was obtained by using the extraction protocol of the p38MAPK immunoassay kit from Invitrogen. The protein concentration was determined by the Bradford method and a $1 \mathrm{mg} / \mathrm{ml}$ bovine serum albumin standard ${ }^{(28)}$. The $\mathrm{pH}$ of the extracted protein samples was adjusted to 8.5 with $3 \mathrm{M}$-Tris, and each extract was labelled by the minimal labelling process, following the manufacturer's instructions. Briefly, $30 \mu \mathrm{g}$ of proteins were labelled with either $240 \mathrm{pmol} C y 3$ or Cy 5 protein labelling dye, respectively. In addition, an internal standard was created by pooling aliquots of all protein extracts obtained, and $30 \mu \mathrm{g}$ labelled with Cy 2 dye. For the labelling, $240 \mathrm{pmol}$ of dye were added to each tube, briefly centrifuged and vortexed and incubated for $30 \mathrm{~min}$ on ice in the dark. To stop the labelling reaction, $1 \mu \mathrm{l}$ of $10 \mathrm{~mm}$-lysine was added; samples were briefly centrifuged, vortexed and incubated for $10 \mathrm{~min}$ on ice in the dark. Afterwards, the Cy3- and Cy5labelled extracts were combined with the Cy2-labelled internal standard (Table 2). The volume was adjusted to $450 \mu \mathrm{l}$ with sample buffer (urea ( $7 \mathrm{~m})$, thio-urea $(2 \mathrm{~m})$, (3-[(3-cholamidopropyl)dimethylammonio]-1-propanesulfonate (0.5\%) and bromophenol blue (traces)), and then $9 \mu$ l of biolyte $\mathrm{pH} 3-$ 10 ampholyte buffer (Bio-Rad, Nazareth-Eke, Belgium) and $2.7 \mu \mathrm{l}$ of destreak reagent were added. A total of $90 \mu \mathrm{g}$ proteins (30 $\mu \mathrm{g}$ per sample and $30 \mu \mathrm{g}$ of internal sample) were thus loaded on each strip and 2D-DIGE was performed. The use of an internal standard reduced the possibility of erroneous conclusions due to different concentration loads or differences between conditions of each strip or gel. The samples were added on an Immobiline DryStrip $(24 \mathrm{~cm}, \mathrm{pH}$ 3-10 non-linear; BioRad) and incubated overnight at room temperature to achieve optimal passive rehydration of the strip and sample loading. Proteins were then subjected to isoelectric focusing on an IPGphore III at $20^{\circ} \mathrm{C}$. Mineral oil was added on the strips to prevent evaporation. The voltage was stepwise increased from 30 to $10000 \mathrm{~V}$ during the first $21 \mathrm{~h}$ and then stabilised at $10000 \mathrm{~V}$ for $8 \mathrm{~h}$ (about $120 \mathrm{kVh}$ of the total current applied in total to each strip). Following the first dimension separation, strips were equilibrated for $15 \mathrm{~min}$ in equilibration buffer (2D Gel DALT; Gelcompany) containing also urea and dithiothreitol, and then for another $15 \mathrm{~min}$ in the same buffer containing iodoacetamide instead of dithiothreitol. After equilibration, strips were loaded on precast gels (2D gel DALT NF 12.5\%; Gelcompany) for seconddimensional separation, carried out on an Ettan DALT II system with $0.5 \mathrm{~W} /$ gel for $2 \mathrm{~h}$ and then $2.5 \mathrm{~W} /$ gel for $14 \mathrm{~h}$ at $25^{\circ} \mathrm{C}$. The gels were scanned using a Typhoon 9400 scanner (Molecular Dynamics Inc.) and analysed by the DeCyder 2D Differential Analysis version 7.0. The protein images were produced by excitation of gels at 488, 532 and $633 \mathrm{~nm}$ (Cy2, Cy3 
Table 2. Experimental design for the proteomic experiment employing two-dimensional differential in-gel electrophoresis following six different carotenoid treatments ( $n 4$ replica each, no. $1-4)^{\star}$

\begin{tabular}{|c|c|c|c|}
\hline Gel no. & Сy2 & Суз & Cy5 \\
\hline 1 & Pooled internal standard & Blank no. 1† & $\beta$-Carotene $25 \mu \mathrm{g} / \mathrm{ml}$ no. $3 \ddagger$ \\
\hline 2 & Pooled internal standard & Blank no. $2 \dagger$ & $\beta$-Carotene $25 \mu \mathrm{g} / \mathrm{ml}$ no. $4 \ddagger$ \\
\hline 3 & Pooled internal standard & Blank/micelles no. $1 \S$ & $\beta$-Carotene $10 \mu \mathrm{g} / \mathrm{ml}$ no. $3 \ddagger$ \\
\hline 4 & Pooled internal standard & Blank/micelles no. $2 \S$ & $\beta$-Carotene $10 \mu \mathrm{g} / \mathrm{ml}$ no. $4 \ddagger$ \\
\hline 5 & Pooled internal standard & Blank/micelles/stimulus no. $1 \|$ & Lycopene $10 \mu \mathrm{g} / \mathrm{ml}$ no. 3q \\
\hline 6 & Pooled internal standard & Blank/micelles/stimulus no. 2\| & Lycopene $10 \mu \mathrm{g} / \mathrm{ml}$ no. 4q \\
\hline 7 & Pooled internal standard & Lycopene $10 \mu \mathrm{g} / \mathrm{ml}$ no. 19 & Blank/micelles/stimulus no. 3\| \\
\hline 8 & Pooled internal standard & Lycopene $10 \mu \mathrm{g} / \mathrm{ml}$ no. 2q & Blank/micelles/stimulus no. $4 \|$ \\
\hline 9 & Pooled internal standard & $\beta$-Carotene $10 \mu \mathrm{g} / \mathrm{ml}$ no. $1 \ddagger$ & Blank/micelles no. $3 \S$ \\
\hline 10 & Pooled internal standard & $\beta$-Carotene $10 \mu \mathrm{g} / \mathrm{ml}$ no. $2 \ddagger$ & Blank/micelles no. $4 \S$ \\
\hline 11 & Pooled internal standard & $\beta$-Carotene $25 \mu \mathrm{g} / \mathrm{ml}$ no. $1 \ddagger$ & Blank no. 3† \\
\hline 12 & Pooled internal standard & $\beta$-Carotene $25 \mu \mathrm{g} / \mathrm{ml}$ no. $2 \ddagger$ & Blank no. 4† \\
\hline
\end{tabular}

*Each cellular protein extract obtained following exposure $(30 \mu \mathrm{g})$ was labelled with one of the three fluorophores (Cy2, Cy3 or Cy5). The pooled internal standard contained equal amounts of protein extracts from each treatment and was labelled with Cy2; the other samples were labelled with Cy3 or Cy5.

† Without stimuli and micelles.

$\ddagger \beta$-Carotene $(10$ or $25 \mu \mathrm{g} / \mathrm{ml})$, cells stimulated with the TNF- $\alpha / \mathrm{IL} 1-\beta$ mixture $(28 \mathrm{~h})$ exposed to micelles containing either 10 or $25 \mu \mathrm{g} \beta$-carotene/ml $(24 \mathrm{~h})$.

$\S$ Without stimuli but with empty micelles (negative control).

\|W With stimuli and empty micelles (positive control), i.e. TNF- $\alpha$ plus IL $1-\beta$ at 100 and $25 \mathrm{ng} / \mathrm{ml}(28 \mathrm{~h}$ ) and exposed to empty micelles for $24 \mathrm{~h}$

I Lycopene $(10 \mu \mathrm{g} / \mathrm{ml})$, cells stimulated with the TNF- $\alpha / \mathrm{IL} 1-\beta$ mixture $(28 \mathrm{~h})$ exposed to micelles containing $10 \mu \mathrm{g}$ lycopene/ml $(24 \mathrm{~h})$.

and Cy5, respectively) and emission at 520, 610 and $670 \mathrm{~nm}$ (Cy2, Cy3 and Cy5, respectively) using the Typhoon 9400 scanner at a spatial resolution of $100 \mu \mathrm{m}$. Selected spots of interest (abundance of variation 1.3-fold, $P<0.05$ ) were located on a gel and a 'picking list' was generated. The spot picking, digestion and the spotting of the samples on matrix-assisted laser desorption/ionisation (MALDI) disposable targets plates (4800; Applied Biosystems) were done automatically using the Ettan Spot Handling Workstation. Peptide mass fingerprint and MS/MS analyses were carried out using the 4800 Proteomics Analyser (Applied Biosystems). Calibration was done with the peptide mass calibration kit 4700 (Applied Biosystems). Proteins were identified by the SWISSPROT database (version 20100924 with 519538 sequences) with 'Homo sapiens' as taxonomy, using GPS Explorer Software version 3.6 (Applied Biosystems) including MASCOT (Matrix Science, www.matrixscience.com). All searches were carried out allowing for a mass window of $150 \mathrm{ppm}$ for the precursor mass and $0.75 \mathrm{Da}$ for fragment ion masses. The search parameters allowed for carboxyamidomethylation of cysteine as fixed modification. Oxidation of methionine and oxidation of tryptophan (single oxidation, double oxidation and kynurenin) were set as variable modifications. Proteins with probability-based MOlecular Weight SEarch (MOWSE) scores $(P<0 \cdot 01)$ were considered as positively identified.

\section{Statistical analysis}

Original data were verified for normality by $Q-Q$ plots and checked for equality of variance by boxplots. Wherever required, data were log-transformed for statistical evaluation. Univariate models were then created with the observed parameters (e.g. IL-8 concentration) as the dependent variable and the different carotenoids and their concentrations (also including the controls) as fixed factors. Following significant Fisher's $F$ tests, individual post hoc tests were carried out to determine differences compared with the control (Dunnet's test). A $P$ value below 0.05 (two-sided) was chosen to indicate significance. Unless otherwise stated, all data are expressed as mean percentages (compared with the positive control) and standard deviations.

\section{Results}

\section{Cell viability, IL-8, PGE-2 $\alpha$ and NO secretion following carotenoid exposure}

The different carotenoid treatments (Table 1) did not result in a significant reduction of Caco- 2 cell viability. Furthermore, treatment with micelles per se $(\mathrm{B} / \mathrm{M})$ and with pro-inflammatory cytokines $(\mathrm{B} / \mathrm{M} / \mathrm{S})$ did not result in significant changes of cell viability (Table 3 ). Mean uptake of $\beta$-carotene into cells was approximately $7 \cdot 2 \%$, and that of lycopene $4.3 \%$.

The addition of TNF- $\alpha$ and IL- $1 \beta$ resulted in a $4 \cdot 1$-fold induction of the IL- 8 secretion compared with the negative control (B; Fig. 1). Neither empty micelles (B/M) nor the addition of lycopene or $\beta$-carotene (10 and $25 \mu \mathrm{g} / \mathrm{ml}$ ) to the Caco- 2 cells did result in any significant effect on the IL- 8 secretion compared with the positive controls (Table 3). PGE-2 production was already high in unstimulated cells ( $\mathrm{B}$ and $\mathrm{B} / \mathrm{M}$ ) compared with the positive control. The addition of TNF- $\alpha$ and IL- $1 \beta$ did not result in any further induction of COX-2 activity. The carotenoid treatment likewise did not show any significant effect (Table 3). Similarly, the NO secretion in unstimulated cells ( $\mathrm{B}$ and $\mathrm{B} / \mathrm{M}$ ) was already high compared with the positive control. The addition of the pro-inflammatory cytokines and the carotenoid treatment had no further significant impact on NO secretion (Table 3). 


\section{$N F-\kappa B$ and mitogen-activated protein kinase}

The influence of the two different carotenoids was also investigated on intracellular signalling cascades via NF-кB and MAPK activation. TNF- $\alpha$ and IL- $1 \beta$ induced the NF- $\kappa \mathrm{B}$ activity 3.2-fold (Fig. 2). Lycopene (10 $\mu \mathrm{g} / \mathrm{ml})$ and $\beta$-carotene (10 and $25 \mu \mathrm{g} / \mathrm{ml}$ ) did not show any significant reduction of the NF-кB activity (Table 3). MAPK activity in unstimulated cells (B and $\mathrm{B} / \mathrm{M}$ ) was already high compared with the positive control, and the carotenoid treatment did not show any further significant reduction of the MAPK activity (Table 3).

\section{Proteomic analyses}

The analysis of the different treatments revealed that overall and within all pairwise comparisons, sixty-five spots were differentially regulated in their expression $(P<0.05$, expression ratio at least $\pm 1 \cdot 3$-fold) and had a unique identification, belonging to fifty-two different proteins (Fig. 3 and Supplementary Table 1; http://www.journals.cambridge.org/bjn). Out of these, fifteen were differentially regulated in their expression due to the lycopene and $\beta$-carotene treatments (Table 4), compared with cells treated with empty micelles and inflammatory stimuli. The fifteen proteins were then classified with respect to their localisation and biological pathway in which they were involved, according to Gene Ontology (http://www.geneontology.org). Most of the proteins were intracellular proteins, predominantly located in the cytoplasm (67\%), predominantly involved in metabolic pathways (34\%) and in the stress response (40\%). Among the fifteen differentially expressed proteins, eleven were differentially expressed following the treatment with $\beta$-carotene at $10 \mu \mathrm{g} /$ $\mathrm{ml}$, three were differentially expressed by $\beta$-carotene at $25 \mu \mathrm{g} / \mathrm{ml}$, one protein was differentially expressed in both $\beta$-carotenoid treatments and one protein was differentially expressed by lycopene $(10 \mu \mathrm{g} / \mathrm{ml})$. From the eleven differentially expressed proteins following the $\beta$-carotene $(10 \mu \mathrm{g} / \mathrm{ml})$ treatment, $82 \%$ were down-regulated, while the three differentially expressed proteins due to the $\beta$-carotene treatment at $25 \mu \mathrm{g} / \mathrm{ml}$ were all up-regulated, compared with the positive control $(M+S)$. The only protein that was differentially expressed following the lycopene $(10 \mu \mathrm{g} / \mathrm{ml})$ treatment was up-regulated (Table 4).

\section{Discussion}

In the present study, we investigated the hypothesis that individual carotenoids might exhibit anti-inflammatory properties on cells resembling the gastrointestinal epithelium, and could constitute a preventive dietary strategy against chronic gut diseases such as UC or CD. We tested the influence of $\beta$-carotene and lycopene in artificial micelles on inflammatory-stimulated Caco-2 cell production of several inflammatory endpoints, including IL, NO, COX-2 activity, intracellular signalling pathways (NF-кB and MAPK) and proteomics. While individual carotenoids at realistic dietary concentrations did not significantly affect inflammatory markers, several proteins were differentially regulated, indicating that carotenoids could 


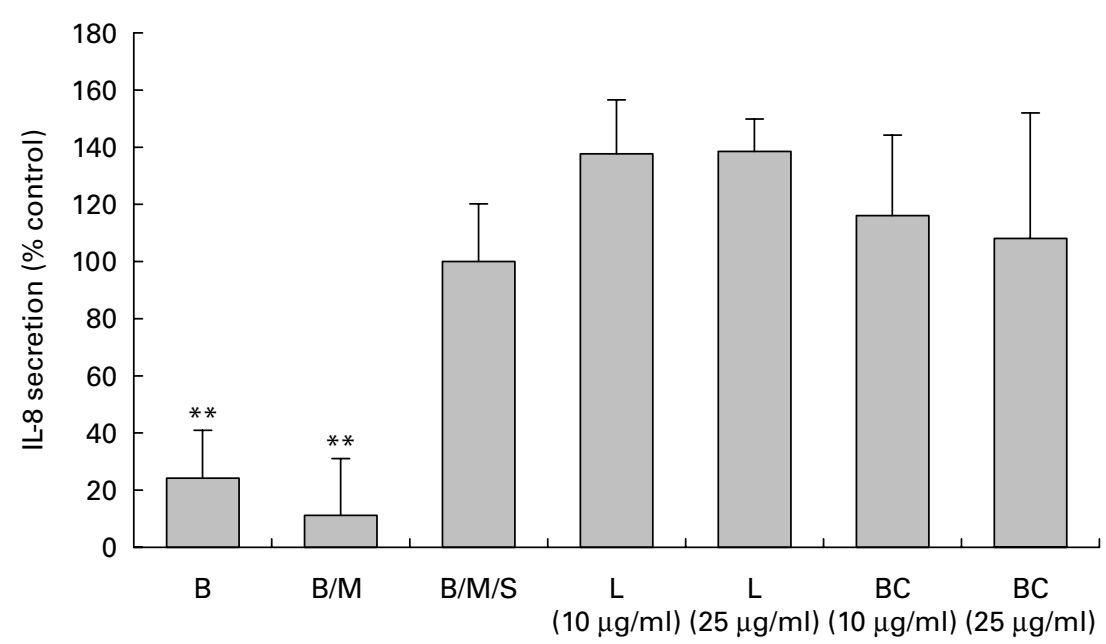

Fig. 1. Effect of carotenoids, lycopene and $\beta$-carotene, on the IL-8 secretion of Caco-2 cells stimulated for inflammation with $\mathrm{TNF}-\alpha(100 \mathrm{ng} / \mathrm{ml})$ and $\mathrm{IL}-1 \beta$ $(25 \mathrm{ng} / \mathrm{ml})$ for $24 \mathrm{~h}$. Cells were exposed to various treatments and the IL- 8 secretion was measured after $28 \mathrm{~h}$. Values are means from six independent replicates compared with the control (blank $(\mathrm{B}) /$ micelles $(\mathrm{M}) /$ stimulus $(\mathrm{S})=100 \%(n 12$ replicates)), with standard deviations represented by vertical bars. B/M, B $+\mathrm{M}$; $\mathrm{B} / \mathrm{M} / \mathrm{S}, \mathrm{B}+\mathrm{M}+\mathrm{S}$; L, lycopene; BC, $\beta$-carotene. ${ }^{\star *}$ Mean values were significantly different by Dunnet's test $(P<0 \cdot 01)$.

alter the general metabolism of these epithelial cells. To our knowledge, this is the first time that the impact of carotenoids on inflammatory markers of the gut epithelium has been studied.

Both $\beta$-carotene and lycopene are found in a wide range of frequently consumed fruits and vegetables. Concentrations tested (10 and $25 \mu \mathrm{g} / \mathrm{ml}$ ) represented high, but still plausible concentrations that could be reached following, for example, consumption of approximately $300 \mathrm{~g}$ carrots, assuming a total volume of gastrointestinal liquids of 1 litre ${ }^{(29)}$. The viability studies conducted indicated that the carotenoids added did not result in adverse effects. Furthermore, micelles alone, without lycopene and $\beta$-carotene, did not result in any significant changes of the inflammatory markers studied.

Both TNF- $\alpha$ and IL-1 $\beta$ used for inflammation stimulation are activators of inflammatory pathways, and have been previously used to study the impact of cytokines on inflammation $^{(30)}$. TNF- $\alpha$ and IL-1 $\beta$ in the present study resulted in inflammatory stimulation, as determined by the $4 \cdot 1$-fold increase in IL-8 and the $3 \cdot 2$-fold increase in NF- $\kappa \mathrm{B}$, albeit they did not significantly change PGE- $2 \alpha$, NO and MAPK. It may be that the exposure time of $24 \mathrm{~h}$ was not long enough to induce the production of $\mathrm{PGE}-2 \alpha$, NO and to activate MAPK. NO production, for example, requires more steps than the production of IL-8. IL-8 expression follows binding

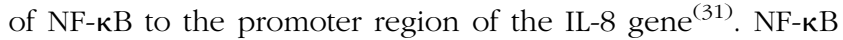
is responsible for the expression of inducible NOS, which then catalyses the reaction of $\mathrm{L}$-arginine into $\mathrm{NO}^{(32)}$. PGE- $2 \alpha$ synthesis involves even more enzymatic steps for activation compared with, for example, IL-8 and NO. Following binding of NF- $\mathrm{KB}, \mathrm{COX}-2$ catalyses the reaction of arachidonic acid to PGG-2 and further to PGH-2. The PG synthase E then catalyses the reaction to PGE- $2 \alpha^{(33)}$. Another factor might be the status of the cells. While our experiments were conducted with 1-week differentiated cells, proliferating cells could respond differently. Van de Walle et $a l{ }^{(30)}$ showed that
PGE-2 concentration was higher in proliferating cells than in differentiated cells, while NO production was detectable only in 3-week differentiated cells. However, inflammation induction following IL-8 and NF- $\mathrm{BB}$ was slightly lower in the present study compared with a similar earlier study ${ }^{(34)}$, with a 7.5- and 5.8-fold increase, respectively. Thus, the inflammation in the present study was rather indicative of a low, chronic type.

IL-8 is a chemokine responsible for the chemotaxis of neutrophiles and their degranulation ${ }^{(35)}$. We did not observe any significant changes of this marker following carotenoid exposure, neither of the regulation of NF- $\mathrm{B}$, being in line with the theory that IL- 8 is regulated via $N F-\kappa B^{(36)}$. As with IL- 8, PGE- $2 \alpha$ is likewise a major mediator of intestinal inflammation $^{(37)}$, resulting from COX-2 activity and arachidonic acid. While in a previous study ${ }^{(38)}$, a similar concentration of arachidonic acid resulted in a 5.6-fold increase of PGE-2, in the present study, PGE- $2 \alpha$ production remained low during all experiments, suggesting that carotenoids were not able to modify the activity of COX-2 significantly.

NO plays a central role in human IBD $^{(39)}$. In the present study, no significant change in NO concentration following carotenoid exposure was observed. Contrarily, RomierCrouzet et $a l .{ }^{(38)}$ showed an increase in NO production after inflammatory stimuli by 1.9-fold; however, stimulation was done for $48 \mathrm{~h}$ and with a mixture of interferon- $\gamma$, IL- $1 \beta$, TNF- $\alpha$ and lipopolysaccharide.

We also investigated the effect of carotenoids on the NF-кB cascade. NF- $\mathrm{B}$ has many target genes, playing an important role in inflammation. In the present study we determined inducible NOS through NO production, COX-2 through PGE- $2 \alpha$ production and the IL- 8 gene through the IL- 8 production. All compounds have been reported to be impacted via the $\mathrm{NF}-\kappa^{\mathrm{B}}$ pathway ${ }^{(16,32,36)}$, albeit they may also be regulated by $\mathrm{NF}-\kappa \mathrm{B}$-independent pathways ${ }^{(40)}$. In this study, the stimulation of Caco- 2 cells with TNF- $\alpha$ and IL- $1 \beta$ resulted in 


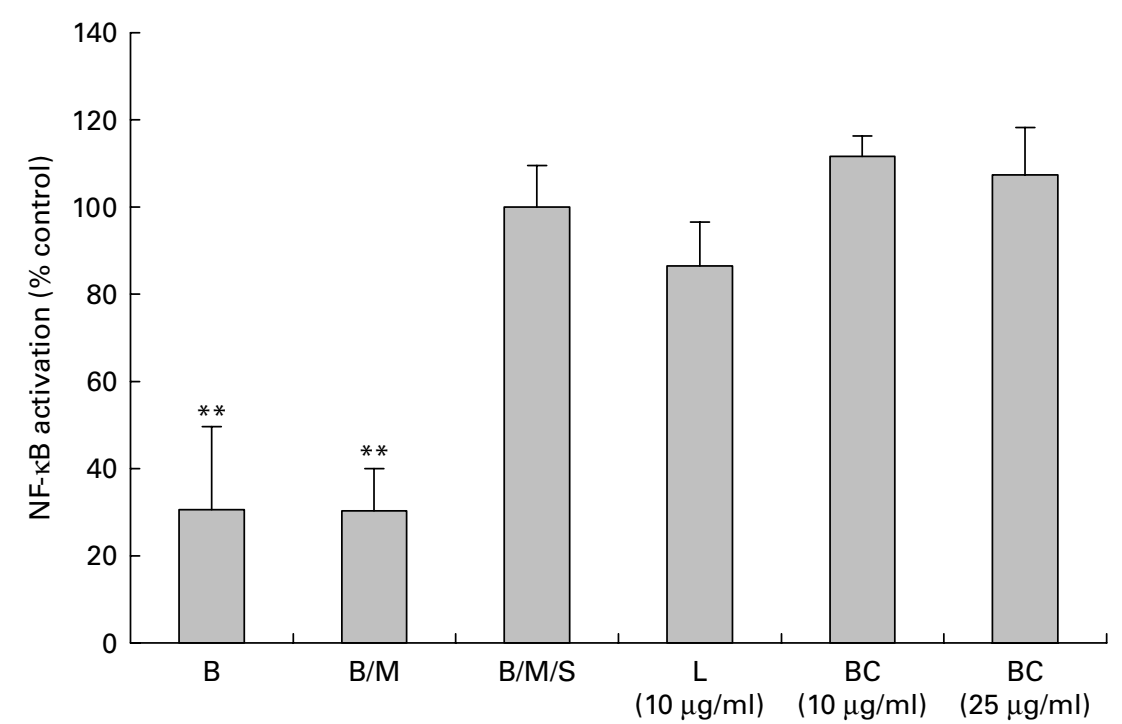

Fig. 2. Effect of the carotenoids on the NF-KB activation of Caco-2 cells stimulated for inflammation with TNF- $\alpha(100 \mathrm{ng} / \mathrm{ml})$ and IL-1 3 (25 ng/ml) for $24 \mathrm{~h}$. The cells were exposed to various treatments and the NF-KB activation was measured after $28 \mathrm{~h}$. Values are means from four replicates of each sample compared with the control (blank $(B) /$ micelles $(M) /$ stimulus $(S)=100 \%$ ), with standard deviations represented by vertical bars. B/M, B + M; B/M/S, B + M + S; L, lycopene; $\mathrm{BC}, \beta$-carotene. Mean values were significanly different by Dunnet's test $(P<0.01)$.

a significant increase in NF- $\mathrm{B}$ compared with the unstimulated $\mathrm{B}$, indicating activation of NF-кB-dependent pathways, as shown by the increased IL- 8 production in the present study.

The MAPK cascades are also involved in the production of inflammatory mediators, three are well-characterised in mammals: extracellular signal-regulated kinases (ERK1/ERK2); c-Jun N-terminal kinases (JNK1, JNK2 and JNK3); p38 kinases $^{(41)}$. The target genes of the p38 kinases are mostly cytokines, and thus play a crucial role in inflammatory responses ${ }^{(41)}$. As the immunoassay kit used during our study detected the total produced p38MAPK (independently of phosphorylation state), we already observed high concentrations of p38 in unstimulated cells, but no further impact following the inflammation trials.

Contrarily to earlier studies suggesting anti-inflammatory properties of $\beta$-carotene and lycopene in cellular trials as measured by NO, PGE-2, inducible NOS and COX-2 ${ }^{(14,42)}$, in the present study, the two carotenoids did not affect NO, IL-8 and COX-2 activity, further confirmed by NF- $\mathrm{KB}$ and

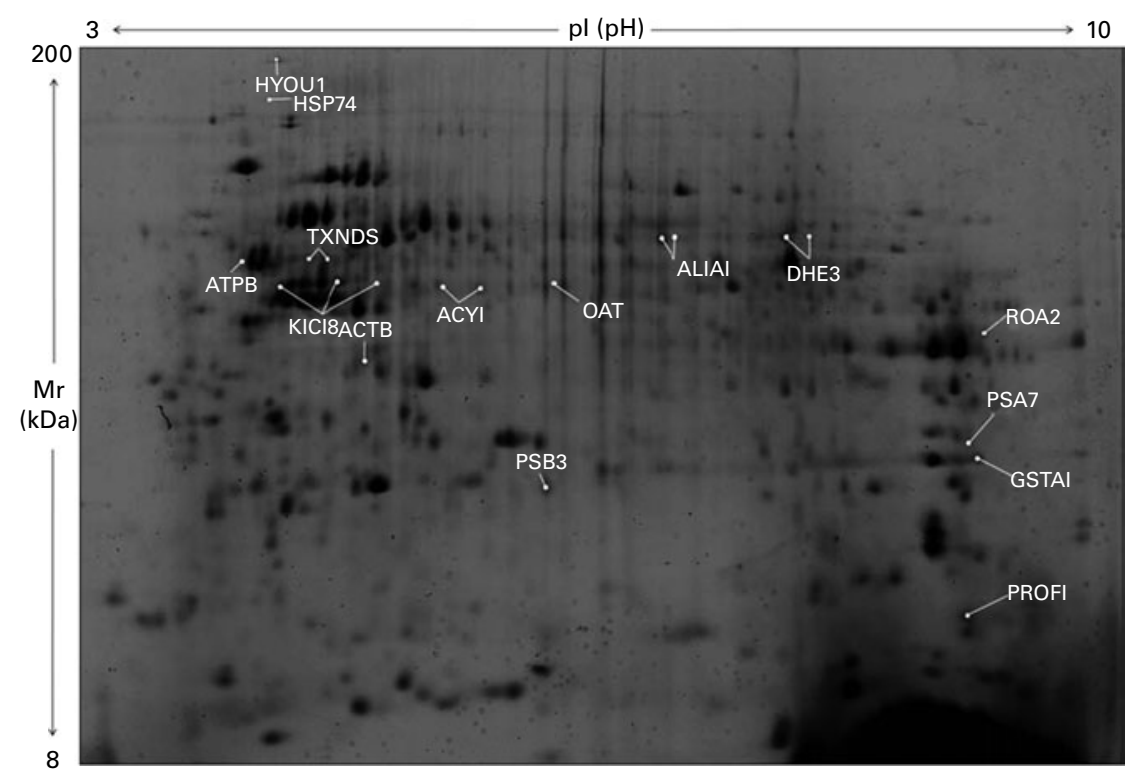

Fig. 3. Differentially expressed protein spots identified following two-dimensional differential in-gel electrophoresis (2D-DIGE) analysis. The 2D-DIGE analysis was done on the whole protein extract from Caco-2 cells which were treated with empty micelles and inflammation stimulus for $24 \mathrm{~h}(\mathrm{TNF}-\alpha(100 \mathrm{ng} / \mathrm{ml}) / \mathrm{LL}-1 \beta$ $(25 \mathrm{ng} / \mathrm{ml}))$, treated with lycopene $(10 \mu \mathrm{g} / \mathrm{ml})$ or $\beta$-carotene $(10$ and $25 \mu \mathrm{g} / \mathrm{ml})$ for $24 \mathrm{~h}$ plus the inflammation stimulus for $28 \mathrm{~h}$. Proteins were separated in the first dimension on a non-linear $\mathrm{pH}$ gradient and in the second dimension on a SDS-PAGE gel. Comparisons were made for each treatment against blank + micelles + inflammation stimulus (control). 
MAPK. The reasons remain speculative. It has been argued that dietary antioxidants, including $\beta$-carotene and lycopene, possess biphasic effects, with higher concentrations resulting even in negative, i.e. pro-oxidative, effects ${ }^{(43)}$.

Despite no effects on selected markers, proteomic analysis revealed that a total of fifteen proteins were differentially expressed following the carotenoid treatments. These proteins were predominately involved in metabolic pathways. About two-thirds of these differentially expressed proteins were present in the cytosol. Lycopene appeared to have a lower impact compared with $\beta$-carotene, as only one protein (profilin-1) was differentially expressed. One explanation could be the low cellular uptake as opposed to $\beta$-carotene ${ }^{(44)}$, also observed in the present study. Profilin-1 is an actin-binding protein, involved in the regulation of the cytoskeleton assembly. It is also able to bind cell membrane components such as phosphatidyl-inositol-4,5-bisphosphate and to regulate the formation of inositol triphosphate, thus acting as a signalling $\operatorname{protein}^{(45)}$.

At intermediate concentrations $(10 \mu \mathrm{g} / \mathrm{ml}), \quad \beta$-carotene resulted rather in a down-regulation of differentially expressed proteins. In contrast, changes induced by $\beta$-carotene at $25 \mu \mathrm{g} / \mathrm{ml}$ were limited to only three proteins, all of which were up-regulated. These included mitochondrial ATP synthase subunit $\beta$, part of the catalytic domain of the ATP synthase and responsible for the formation of ATP from ADP and inorganic phosphate; cytoskeletal keratin type I constituting a component of the intermediate filaments exerting vital structural functions in eukaryotic cells and also involved in regulatory processes, including apoptosis modulation ${ }^{(46)}$; and thioredoxin domain-containing protein 5, involved in the resistance to nitrosative stress ${ }^{(47)}$.

Most proteins down-regulated by $\beta$-carotene at $10 \mu \mathrm{g} / \mathrm{ml}$ are potentially involved in inflammation. For example, glutathione transferase participates in the elimination of xenobiotics, and glutathione is a major endogenous antioxidant, important for controlling pro-inflammatory processes ${ }^{(48)}$. The reduced activity of these enzymes observed may be representative of a decreased cellular stress following carotenoid exposure. Hypoxia up-regulated protein 1 has an important role in response to hypoxia-induced stress, modulating apoptosis. Furthermore, up-regulated were heterogeneous nuclear ribonucleoproteins $\mathrm{A} 2 / \mathrm{B} 1$ and heat shock protein $70 \mathrm{kDa}$ protein 4 , the former being involved in mRNA maturation and processing, the latter in folding and assembly of proteins, as well as in stress response.

Caco-2 cells have been frequently employed in various studies; however, it is also important to point out the limitations of this model. While Caco-2 cells resemble the human intestinal epithelium, they are of neoplastic origin and might therefore differ in features from the natural intestine. Caco-2 cells further are monolayers mimicking only enterocytes, therefore lacking, for example, the mucus layer. Nevertheless, Caco-2 cells express various transporter and efflux proteins and have been frequently used for investigating bioavailability aspects of various compounds ${ }^{(49,50)}$ and also for stimulating intestinal inflammation ${ }^{(30,38)}$. In addition, Caco- 2 cells express various transporter proteins 
and efflux proteins. Finally, it cannot be excluded that the artificial system chosen here for carotenoid emulsification could have compromised the uptake of carotenoids and therefore their influence on Caco- 2 cells, as artificial micelles could differ from micelles formed during the normal gastrointestinal digestion, for example in terms of size and release kinetics of carotenoids.

In summary, $\beta$-carotene and lycopene were not able to show significant effects on selected inflammatory mediators in stimulated Caco- 2 cells, albeit the proteomic results indicate that several pathways related to inflammation, such as antioxidative enzymes, were involved. More studies in this domain, examining different carotenoids, and perhaps mixtures representing more natural conditions, are warranted.

\section{Acknowledgements}

We thank Servane Contal, Boris Untereiner and Sébastien Planchon for their valuable technical assistance, and Eric Biehler for his support. We further thank the Luxembourgish Fonds National de la Recherche for their support (grant no. FNR/ CORE 2010/819345). There is no conflict of interest. T. B. and A. K. planned the experiments, performed the statistical evaluation and wrote the manuscript, and A. K. conducted the majority of the experiments. T. S. and J. R. were responsible for the proteomic analyses and interpretations. L. H. is the head of Department, and was involved in the project planning, as well as in corrections and interpretations of the final manuscript.

\section{References}

1. Bohn T (2008) Bioavailability of non-provitamin A carotenoids. Curr Nutr Food Sci 4, 240-258.

2. Giovannucci E (2002) A review of epidemiologic studies of tomatoes, lycopene, and prostate cancer. Exp Biol Med (Maywood) 227, 852-859.

3. Nishino H, Tokuda H, Murakoshi M, et al. (2000) Cancer prevention by natural carotenoids. Biofactors 13, 89-94.

4. Britton G (1995) Structure and properties of carotenoids in relation to function. FASEB J 9, 1551-1558.

5. Riccioni G, D'Orazio N, Speranza L, et al. (2010) Carotenoids and asymptomatic carotid atherosclerosis. J Biol Regul Homeost Agents 24, 447-452.

6. Coyne T, Ibiebele TI, Baade PD, et al. (2005) Diabetes mellitus and serum carotenoids: findings of a population-based study in Queensland, Australia. Am J Clin Nutr 82, 685-693.

7. Hozawa A, Jacobs DR Jr, Steffes MW, et al. (2006) Associations of serum carotenoid concentrations with the development of diabetes and with insulin concentration: interaction with smoking: the Coronary Artery Risk Development in Young Adults (CARDIA) Study. Am J Epidemiol 163, 929-937.

8. Waris G \& Ahsan H (2006) Reactive oxygen species: role in the development of cancer and various chronic conditions. $J$ Carcinog 5, 14.

9. Mayne ST (1996) Beta-carotene, carotenoids, and disease prevention in humans. FASEB J 10, 690-701.

10. Wendland BE, Aghdassi E, Tam C, et al. (2001) Lipid peroxidation and plasma antioxidant micronutrients in Crohn disease. Am J Clin Nutr 74, 259-264.
11. Droge W (2002) Free radicals in the physiological control of cell function. Physiol Rev 82, 47-95.

12. Karrasch T \& Jobin C (2008) NF-kappaB and the intestine: friend or foe? Inflamm Bowel Dis 14, 114-124.

13. Jantchou P, Monnet E \& Carbonnel F (2006) Environmental risk factors in Crohn's disease and ulcerative colitis (excluding tobacco and appendicectomy). Gastroenterol Clin Biol 30, 859-867.

14. Bai SK, Lee SJ, Na HJ, et al. (2005) Beta-carotene inhibits inflammatory gene expression in lipopolysaccharidestimulated macrophages by suppressing redox-based NF-kappaB activation. Exp Mol Med 37, 323-334.

15. Head KA \& Jurenka JS (2003) Inflammatory bowel disease. Part 1: ulcerative colitis - pathophysiology and conventional and alternative treatment options. Altern Med Rev 8, $247-283$.

16. Head K \& Jurenka JS (2004) Inflammatory bowel disease. Part II: Crohn's disease - pathophysiology and conventional and alternative treatment options. Altern Med Rev 9, $360-401$.

17. Jowett SL, Seal CJ, Pearce MS, et al. (2004) Influence of dietary factors on the clinical course of ulcerative colitis: a prospective cohort study. Gut 53, 1479-1484.

18. Rumi G Jr, Szabo I, Vincze A, et al. (2000) Decrease of serum carotenoids in Crohn's disease. J Physiol Paris 94, $159-161$.

19. Hengstermann S, Valentini L, Schaper L, et al. (2008) Altered status of antioxidant vitamins and fatty acids in patients with inactive inflammatory bowel disease. Clin Nutr 27, 571-578.

20. Reimund JM, Arondel Y, Escalin G, et al. (2005) Immune activation and nutritional status in adult Crohn's disease patients. Dig Liver Dis 37, 424-431.

21. Maor I, Rainis T, Lanir A, et al. (2008) Oxidative stress, inflammation and neutrophil superoxide release in patients with Crohn's disease: distinction between active and nonactive disease. Dig Dis Sci 53, 2208-2214.

22. D'Odorico A, Bortolan S, Cardin R, et al. (2001) Reduced plasma antioxidant concentrations and increased oxidative DNA damage in inflammatory bowel disease. Scand $J$ Gastroenterol 36, 1289-1294.

23. Guslandi M (1998) Nitric oxide and inflammatory bowel diseases. Eur J Clin Invest 28, 904-907.

24. Stein RB, Lichtenstein GR \& Rombeau JL (1999) Nutrition in inflammatory bowel disease. Curr Opin Clin Nutr Metab Care 2, 367-371.

25. Chantret I, Rodolosse A, Barbat A, et al. (1994) Differential expression of sucrase-isomaltase in clones isolated from early and late passages of the cell line Caco-2: evidence for glucose-dependent negative regulation. J Cell Sci 107, (Pt 1), 213-225.

26. Biehler E, Hoffmann L, Krause E, et al. (2011) Divalent minerals decrease micellarization and uptake of caroteroids and digestion products into Caco-2 cells. J Nutr 141, 1769-1776.

27. Lasserre JP, Fack F, Revets D, et al. (2009) Effects of the endocrine disruptors atrazine and PCB 153 on the protein expression of MCF-7 human cells. J Proteome Res $\mathbf{8}$, 5485-5496.

28. Kruger NJ (1994) The Bradford method for protein quantitation. Methods Mol Biol 32, 9-15.

29. Souci SW, Fachmann W \& Kraut H (1994) Food Composition and Nutrition Tables, 6th ed. Garching: Medpharm.

30. Van De Walle J, Hendrickx A, Romier B, et al. (2010) Inflammatory parameters in Caco-2 cells: effect of stimuli nature, 
concentration, combination and cell differentiation. Toxicol In vitro 24, 1441-1449.

31. Kunsch C \& Rosen CA (1993) NF-kappa B subunit-specific regulation of the interleukin-8 promoter. Mol Cell Biol 13, 6137-6146.

32. Gookin JL, Chiang S, Allen J, et al. (2006) NF-kappaBmediated expression of iNOS promotes epithelial defense against infection by Cryptosporidium parvum in neonatal piglets. Am J Physiol Gastrointest Liver Physiol 290, G164-G174.

33. Simmons DL, Botting RM \& Hla T (2004) Cyclooxygenase isozymes: the biology of prostaglandin synthesis and inhibition. Pharmacol Rev 56, 387-437.

34. Romier B, Van De Walle J, During A, et al. (2008) Modulation of signalling nuclear factor-kappaB activation pathway by polyphenols in human intestinal Caco-2 cells. Br J Nutr 100, 542-551.

35. Waugh DJ \& Wilson C (2008) The interleukin-8 pathway in cancer. Clin Cancer Res 14, 6735-6741.

36. Wang S, Liu Z, Wang L, et al. (2009) NF-kappaB signaling pathway, inflammation and colorectal cancer. Cell Mol Immunol 6, 327-334.

37. Subbaramaiah K, Yoshimatsu K, Scherl E, et al. (2004) Microsomal prostaglandin E synthase-1 is overexpressed in inflammatory bowel disease. Evidence for involvement of the transcription factor Egr-1. J Biol Chem 279, 12647-12658.

38. Romier-Crouzet B, Van de Walle J, During A, et al. (2011) Inhibition of inflammatory mediators by polyphenolic plant extracts in human intestinal Caco-2 cells. Food Chem Toxicol 47, 1221-1230.

39. Rachmilewitz D, Stamler JS, Bachwich D, et al. (1995) Enhanced colonic nitric oxide generation and nitric oxide synthase activity in ulcerative colitis and Crohn's disease. Gut 36, 718-723.

40. Chung EY, Roh E, Kwak JA, et al. (2010) alphaViniferin suppresses the signal transducer and activation of transcription-1 (STAT-1)-inducible inflammatory genes in interferon-gamma-stimulated macrophages. I Pharmacol Sci 112, 405-414.

41. Johnson GL \& Lapadat R (2002) Mitogen-activated protein kinase pathways mediated by ERK, JNK, and p38 protein kinases. Science 298, 1911-1912.

42. De SD, Maiuri MC, Simeon V, et al. (2007) Lycopene, quercetin and tyrosol prevent macrophage activation induced by gliadin and IFN-gamma. Eur J Pharmacol 566, 192-199.

43. Bouayed J \& Bohn T (2010) Exogenous antioxidants double-edged swords in cellular redox state: health beneficial effects at physiologic doses versus deleterious effects at high doses. Oxid Med Cell Longev 3, 228-237.

44. Unlu NZ, Bohn T, Francis DM, et al. (2007) Lycopene from heat-induced cis-isomer-rich tomato sauce is more bioavailable than from all-trans-rich tomato sauce in human subjects. Br J Nutr 98, 140-146.

45. Machesky LM \& Poland TD (1993) Profilin as a potential mediator of membrane-cytoskeleton communication. Trends Cell Biol 3, 381-385.

46. Caulin C, Ware CF, Magin TM, et al. (2000) Keratin-dependent, epithelial resistance to tumor necrosis factor-induced apoptosis. J Cell Biol 149, 17-22.

47. Lee HW, Hitchcock TM, Park SH, et al. (2010) Involvement of thioredoxin domain-containing 5 in resistance to nitrosative stress. Free Radic Biol Med 49, 872-880.

48. Rahman I \& MacNee W (2000) Oxidative stress and regulation of glutathione in lung inflammation. Eur Respir J 16 $534-554$

49. Garrett DA, Failla ML \& Sarama RJ (1999) Development of an in vitro digestion method to assess carotenoid bioavailability from meals. J Agric Food Chem 47, 4301-4309.

50. Ferruzzi MG, Lumpkin JL, Schwartz SJ, et al. (2006) Digestive stability, micellarization, and uptake of beta-carotene isomers by Caco-2 human intestinal cells. J Agric Food Chem 54, 2780-2785. 